\title{
RESEARCH IN DISTRIBUTION OF PRESSURE IN SOIL DEPTH UNDER WHEELS OF DIFFERENT MACHINES
}

\author{
Nicoleta Ungureanu ${ }^{1}$, Valentin Vladut ${ }^{2}$, Sorin-Stefan Biris ${ }^{1}$, Mihai Matache ${ }^{2}$ \\ ${ }^{1}$ University Politehnica of Bucharest, Romania; ${ }^{2}$ National Institute of Research-Development for \\ Machines and Installations Designed to Agriculture and Food Industry, Romania \\ nicoletaung@yahoo.com, valentin_vladut@yahoo.com, biris.sorinstefan@gmail.com, \\ gabimatache@yahoo.com
}

\begin{abstract}
As a result of climate change, a significant increase in population at global level and consequently of food needs, the soil is continuously subjected to the risk of degradation. One type of soil degradation is the artificial compaction, which is recognized by the European Union as a major problem for the environment and agriculture. Occurring as a result of the development of mechanized agriculture that involves the use of heavy machinery for agricultural works, often performed on soils with high moisture, compaction can reduce the agricultural production by up to $60 \%$. In Romania, artificial compaction affects about 6.5 million hectares of arable soil, and natural compaction is found on about 2 million hectares. Compaction is influenced by the factors such as the soil moisture, soil type, external load, tire inflation pressure, shape of the contact area between soil and tire, number of passes on the soil. The paper presents the results of experimental research conducted in the laboratory, which aimed to determine the distribution of stresses in the soil for various conditions. Wheels of two agricultural machines were tested at three inflation pressures: 100, 150 and $200 \mathrm{kPa}$. The compressive force on the wheel was applied by means of a $10 \mathrm{kN}$ cylinder from the Hydropuls installation for testing in simulated and accelerated regime. The FlexiForce Tekscan force sensors have been mounted in the container at eight soil depths: $5,10,15,20,30,35,40$ and $45 \mathrm{~cm}$. Diagrams showing the variation of pressure in the soil at the tested depths were obtained for the applied force, showing that the pressure applied on the soil has uneven variation to a depth of 30-35 cm, and then follows a downward curve with increasing depth.
\end{abstract}

Keywords: soil, agricultural machinery, compaction, pressure, sensor.

\section{Introduction}

Soil degradation, an actual threat in terms of sustainability, is defined as "the current and/or future reduction in its capacity to perform ecosystem functions and services (including those of agroecosystems and urban systems) that support society and development" [1]. A widespread form of soil degradation is compaction, emerged as a consequence of the enhancement of mechanized agriculture that uses heavier machinery, which affects both the environment and agriculture. All farming operations, including seedbed preparation, fertilizer and chemical applications, harvesting and transport increase the risk of degradation of agricultural soil by artificial compaction.

Soil compaction is reduction of the soil volume and increase of the bulk density, mainly produced by the compressive loads (or wheel loads) applied on the soil surface by agricultural machinery [2]. It has been estimated that nearly $4 \%$ of soil throughout Europe suffers from compaction, but no recent and precise data are available. More than a third of the soils in Europe are highly susceptible to compaction in the subsurface layers. In Central and Eastern Europe, 25 million hectares are lightly compacted and 36 million hectares are severely compacted [3].

Footprint is "the portion of the wheel that comes in contact with a supporting surface" [4] or the interface through which the forces applied by agricultural machinery on soil surface are transmitted into soil depth. Due to these forces, the agricultural soil becomes compacted and its functions and quality are altered. Compaction does not affect only the energy consumption for agricultural works, but also the development and growth of crops, food sustainability and the economic stability of farmers.

Due to the large contact area of the tire with deformable soil, the pressure on the soil is lower than when the tire is running on a hard surface. However, the pressure on the soil sometimes exceeds the permissible limit for protecting the soil structure. The requirement is that the pressure applied by the tire on the soil should not exceed $10 \mathrm{~N} \cdot \mathrm{cm}^{-2}$ for field works and $30-35 \mathrm{~N} \cdot \mathrm{cm}^{-2}$ for transport on field roads. Experimental data show that, in general, the minimum limit of $10 \mathrm{~N} \cdot \mathrm{cm}^{-2}$ is respected by the drive wheels of tractors with large diameter tires, for which the soil pressure is around $10 \mathrm{~N} \cdot \mathrm{cm}^{-2}$, but is overtaken by the front (steering) wheels, for which the soil pressure is around $20 \mathrm{~N} \cdot \mathrm{cm}^{-2}$. For transport trailers, the pressure on the soil often exceeds the limit pressure of $35 \mathrm{~N} \cdot \mathrm{cm}^{-2}$. To avoid soil 
compaction, with all its negative consequences, it is necessary to apply some measures in the operation of tires to reduce their pressure on the soil, knowing that it depends on: tire (wheel) load, tire inflation pressure, tire dimensions and tread pattern, tire rigidity, etc [5].

Distribution of pressure into soil depth is influenced by the factors such as: contact area between tire and soil, wheel load, tire inflation pressure, soil moisture and tire design. According to [6], the vertical pressure down to $1 \mathrm{~m}$ depth depends both on the soil contact pressure and wheel load. Tire inflation pressure is one of the most important factors influencing compaction under tires [7] because it modifies the contact area and contact pressure at soil- tire interface for a given load [8].

During agricultural works, if higher tire inflation pressure is used, smaller footprint area is formed, soil deformation increases and the pressure is distributed deeper into the soil (in this case, deep loosening is needed to alleviate the compaction). Using lower tire inflation pressure, tire deformation increases, footprint area increases, contact pressure decreases, soil deformations are smaller and the pressure is transmitted to shallower depths [9]. Also, the benefits of lower inflation pressures might include increased tire performance, decreased soil compaction and smoother ride [10].

The distribution of compaction with soil depth is also important in the design of agricultural machinery and equipment. Since the forces applied by these machines to the soil are very difficult to estimate directly, in many studies empirical methods are used instead: various machines operate on the soil, after which the compaction, which is usually indicated by changes in the soil bulk density and in penetration resistance, is measured. Although compacted soils are found in most regions of the world, the negative economic impact of artificial compaction is obviously most severe in countries most dependent on agriculture for their incomes [11]. Knowing soil behaviour under the wheels of agricultural machinery is very important especially for farmers, because optimization of soil pressure is a useful method to minimize the negative effects of topsoil compaction (to a depth of $300 \mathrm{~mm}$ ) and subsoil compaction (below $300 \mathrm{~mm}$ ). Hence, worldwide, researches and the efforts in technology transfer have increased the awareness on soil compaction.

The aim of this study was mainly to simulate the distribution of pressure with soil depth, under the wheels of a tractor and a harvester, if they would operate with different tire inflation pressures on agricultural soil, and thus to identify the depth, at which the artificial compaction would be more pronounced. In this research, discussions are restricted to distributions that occur in a plane perpendicular to the surface of the soil on which the machine operates.

\section{Materials and methods}

Experimental research to determine the pressure at different soil depths was conducted in laboratory conditions, using a complex testing system that works in simulated and accelerated regime, Hydropuls type (Fig. 1), which can simulate the static pressure at compression of the tires on the soil (stationary machinery). A container made of reinforced sheet with thickness of $3 \mathrm{~mm}$ was filled with soil (Fig. 2).

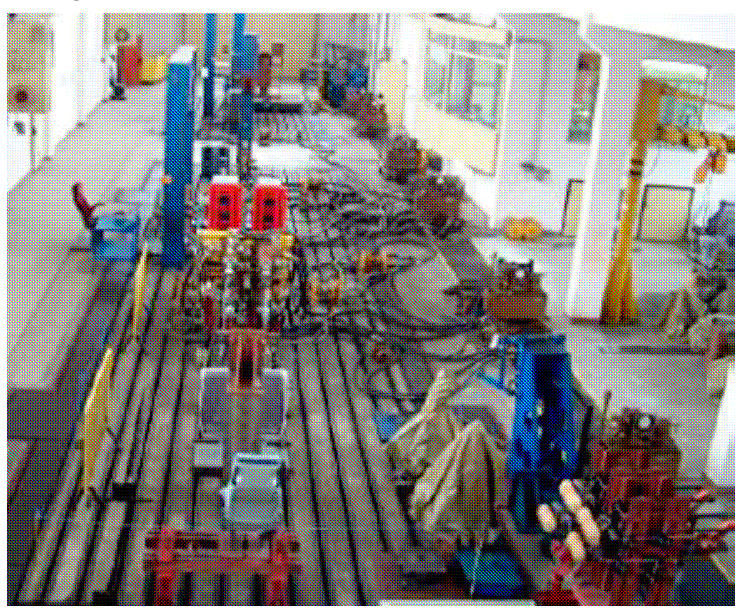

Fig. 1. Hydropuls installation for testing in simulated and accelerated regime

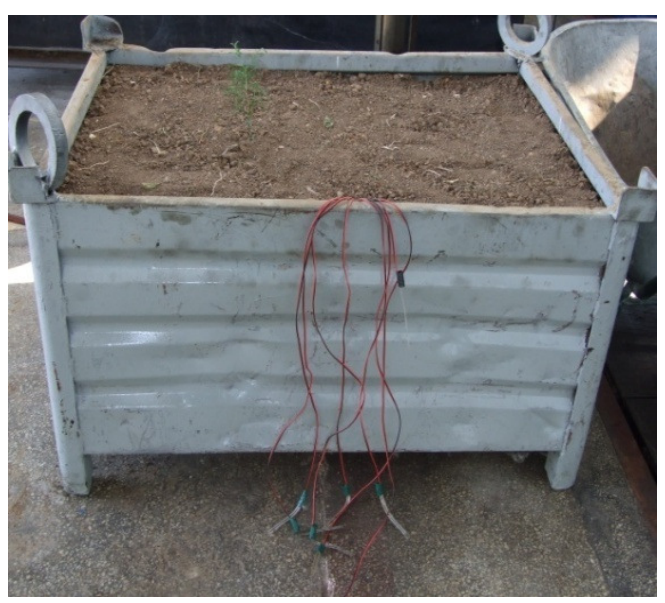

Fig. 2. Container filled with soil 
Eight sensors for force measurement, Flexi Force Tekscan type W-B201-L (Fig. 3) with the maximum domain of $10 \mathrm{~N} / 50.24 \mathrm{~mm}^{2}$ and the diameter of contact button of $0.8 \mathrm{~cm}$ were mounted in the container at depths of $5,10,15,20,30,35,40$ and $45 \mathrm{~cm}$. The connection between the laptop and force measurement sensors was achieved through an adaptation module, formed by amplifiers and analog-to-digital converter, coupled to a serial interface 4RS232 to coupling view (USB), an adaptation module (acquisition system) and laptop.
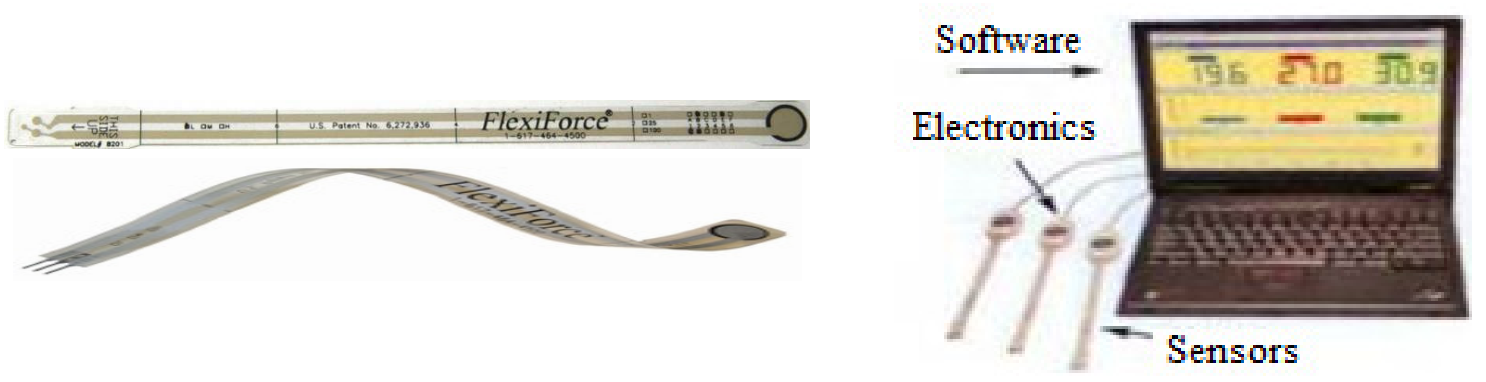

Fig. 3. Flexi Force Tekscan type W-B201-L

A $10 \mathrm{kN}$ hydraulic cylinder and some intermediate devices in the Hydropuls (Fig. 4) were used to simulate the static compression pressure of the wheels on the soil for two following agricultural machines:

- Rear wheel of maize harvester (tire 7.5-20, 8PR D-191).

- Front (steering) wheel of $40 \mathrm{~kW}$ New Holland tractor (tire 18.4-26, 8PR D-165R3).
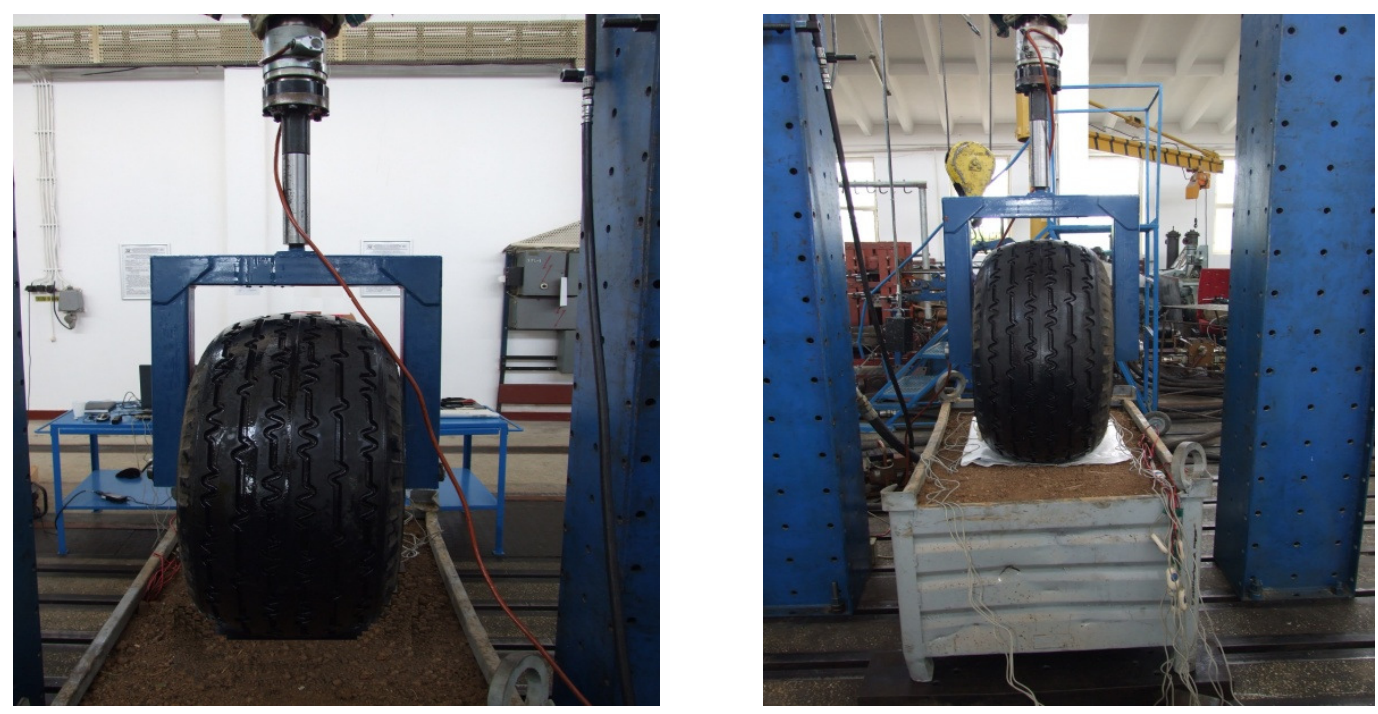

Fig. 4. Simulation of static compression pressure for tire of corn harvester

For the tested wheels, the tire inflation pressure was varied to 100,150 and $200 \mathrm{kPa}$. The footprints between the tire and soil (at the soil surface) were recorded on indigo paper (Fig. 5) and their contour was measured to determine the contact area.

\section{Results and discussion}

The pressure exerted on the soil was determined at the 8 depths, at which the force sensors were applied to the soil, on the direction of action of the compressing force. For each wheel, at each tire inflation pressure, three replication tests were made and the average values are presented next.

The size of the contact area at the soil surface was recorded using indigo paper. For depths between $5-45 \mathrm{~cm}$, size of contact area reffers to the surface of FlexiForce sensor in contact with the soil, which was computed as: $S=\pi \cdot R^{2}=3.14 \cdot 0.16=0.5024 \mathrm{~cm}^{2}$. 


\section{Rear wheel of the maize harvester}

To simulate the pressure exerted by the rear wheel of the maize harvester, for each tire inflation pressure, a compressive force was progressively applied to the wheel by a hydraulic cylinder until it reached the value determined in real conditions (by weighing the maize harvested and determining the distribution on the axles and on the wheels), at which time the forces were measured at each of the 8 depths using the force sensors.

Thus, at the tire inflation pressure of $100 \mathrm{kPa}$, the duration of load was 35 seconds, until the compressive force of $3583 \mathrm{~N}$ was reached; at the tire inflation pressures of $150 \mathrm{kPa}$ and $200 \mathrm{kPa}$, the duration of load was 34.6 seconds, until the compressive forces of $3686 \mathrm{~N}$ and $3560 \mathrm{~N}$ were reached.

Table 1

Static compression test for the maize harvester

\begin{tabular}{|c|c|c|c|c|}
\hline $\begin{array}{c}\text { Sensor } \\
\text { No. }\end{array}$ & $\begin{array}{c}\text { Depth of } \\
\text { sensor, cm }\end{array}$ & $\begin{array}{l}\text { Compressing } \\
\text { force, } \mathbf{N}\end{array}$ & $\begin{array}{c}\text { Size of } \\
\text { contact area, } \\
\mathrm{cm}^{2} \\
\end{array}$ & $\begin{array}{c}\text { Presssure } \\
\text { in the soil, } \\
\mathrm{N} \cdot \mathrm{cm}^{-2} \\
\end{array}$ \\
\hline \multicolumn{5}{|c|}{ Tire inflation pressure $100 \mathrm{kPa}$} \\
\hline- & 0 & 3583 & 624 & 5.7420 \\
\hline 1 & 5 & 14.3226 & 0.5024 & 28.5084 \\
\hline 2 & 10 & 11.8180 & 0.5024 & 23.5230 \\
\hline 3 & 15 & 16.6978 & 0.5024 & 29.2552 \\
\hline 4 & 20 & 11.3336 & 0.5024 & 22.5589 \\
\hline 5 & 30 & 10.2202 & 0.5024 & 20.3427 \\
\hline 6 & 35 & 10.7816 & 0.5024 & 21.4602 \\
\hline 7 & 40 & 12.0915 & 0.5024 & 20.0675 \\
\hline 8 & 45 & 11.7604 & 0.5024 & 23.4084 \\
\hline \multicolumn{5}{|c|}{ Tire inflation pressure $150 \mathrm{kPa}$} \\
\hline- & 0 & 3686 & 575 & 6.4104 \\
\hline 1 & 5 & 15.8187 & 0.5024 & 31.4863 \\
\hline 2 & 10 & 12.5704 & 0.5024 & 25.0207 \\
\hline 3 & 15 & 17.7560 & 0.5024 & 35.3424 \\
\hline 4 & 20 & 12.8118 & 0.5024 & 25.5012 \\
\hline 5 & 30 & 9.9340 & 0.5024 & 19.7731 \\
\hline 6 & 35 & 10.7934 & 0.5024 & 21.4837 \\
\hline 7 & 40 & 12.3665 & 0.5024 & 24.6148 \\
\hline 8 & 45 & 11.5945 & 0.5024 & 23.0782 \\
\hline \multicolumn{5}{|c|}{ Tire inflation pressure $200 \mathrm{kPa}$} \\
\hline- & 0 & 3560 & 538 & 6.6171 \\
\hline 1 & 5 & 16.1764 & 0.5024 & 32.1982 \\
\hline 2 & 10 & 13.1744 & 0.5024 & 26.2229 \\
\hline 3 & 15 & 18.2678 & 0.5024 & 36.3611 \\
\hline 4 & 20 & 13.6482 & 0.5024 & 27.1660 \\
\hline 5 & 30 & 10.9550 & 0.5024 & 21.8252 \\
\hline 6 & 35 & 10.8838 & 0.5024 & 21.6636 \\
\hline 7 & 40 & 11.4672 & 0.5024 & 22.8248 \\
\hline 8 & 45 & 12.0789 & 0.5024 & 24.0424 \\
\hline
\end{tabular}

Figure 6 shows the variation of pressure recorded by the FlexiForce sensors, depending on the soil depth. It can be noticed that regardless the tire inflation pressure, the pressure exerted on the soil tends to decrease as the depth decreases to a depth of $10 \mathrm{~cm}$, then an increase was recorded to a depth of 15 $\mathrm{cm}$, and below this depth the pressure follows a downward curve up to a depth of $35 \mathrm{~cm}$. At $40 \mathrm{~cm}$, for $150 \mathrm{kPa}$ and $200 \mathrm{kPa}$ occurs a slight increase of the soil pressure and at $100 \mathrm{kPa}$ the pressure decreases. 


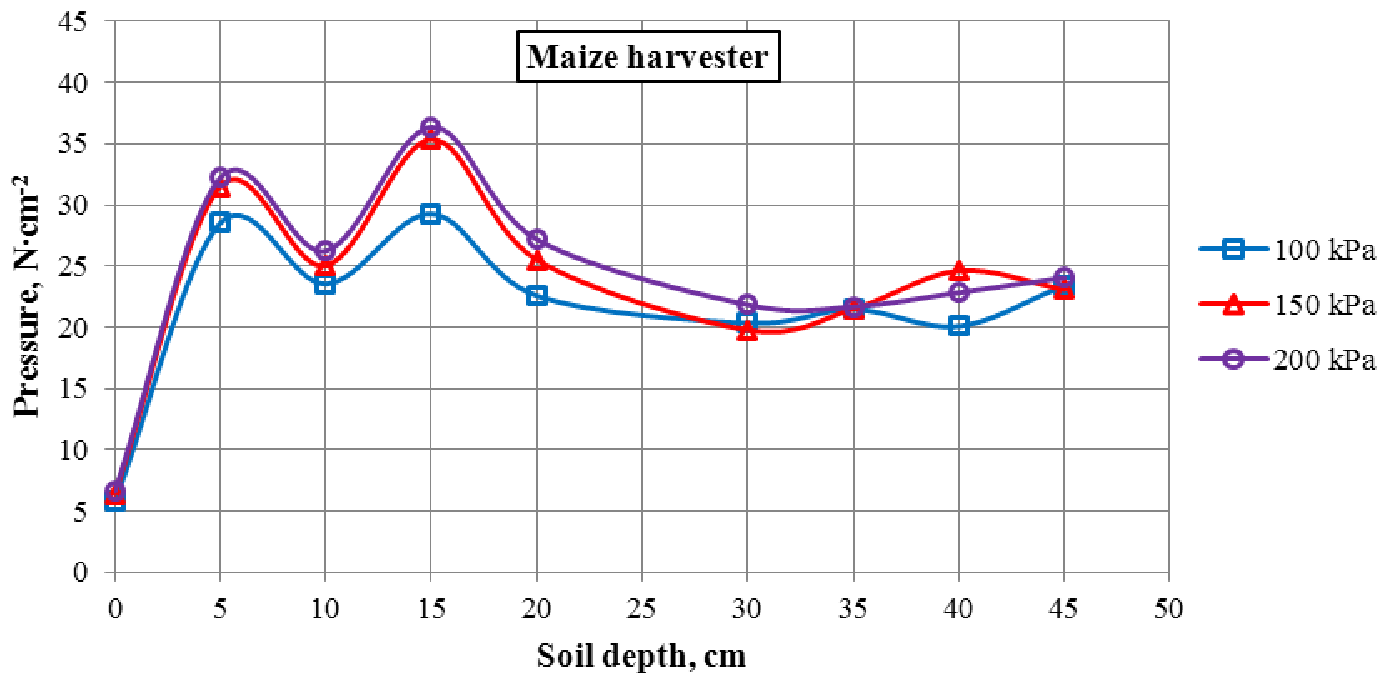

Fig. 6. Variation of pressure with soil depth, under rear wheel of maize harvester

\section{Front wheel of the $\mathbf{4 0} \mathrm{kW}$ New Holland tractor}

To simulate the pressure exerted by the front wheel of the $40 \mathrm{~kW}$ Hew Holland tractor, the same procedure was followed as in the case of the maize harvester. At the tire inflation pressure of $100 \mathrm{kPa}$, the duration of load was 37.8 seconds, until the compressive force of $5749 \mathrm{~N}$ was reached; at the tire inflation pressure of $150 \mathrm{kPa}$, the duration of load was 28 seconds, until the compressive force of 5575 $\mathrm{N}$ was reached, respectively at the tire inflation pressure of $200 \mathrm{kPa}$, the duration of load was 38.3 seconds, until the compressive force of $5658 \mathrm{~N}$ was reached.

Table 2

Static compression test for the tractor

\begin{tabular}{|c|c|c|c|c|}
\hline $\begin{array}{c}\text { Sensor } \\
\text { No. }\end{array}$ & $\begin{array}{c}\text { Depth of } \\
\text { sensor, cm }\end{array}$ & $\begin{array}{c}\text { Compressing } \\
\text { force, } \mathbf{N}\end{array}$ & $\begin{array}{c}\text { Size of } \\
\text { contact area, } \\
\mathbf{c m}^{\mathbf{2}}\end{array}$ & $\begin{array}{c}\text { Presssure } \\
\text { in the soil, } \\
\mathbf{N} \cdot \mathbf{c m}^{-2}\end{array}$ \\
\hline \multicolumn{5}{|c|}{ Tire inflation pressure 100 kPa } \\
\hline- & 0 & 5749 & 1009 & 5.6977 \\
\hline 1 & 5 & 11.9050 & 0.5024 & 23.6963 \\
\hline 2 & 10 & 9.7784 & 0.5024 & 19.4634 \\
\hline 3 & 15 & 14.9246 & 0.5024 & 29.7066 \\
\hline 4 & 20 & 9.9091 & 0.5024 & 19.7235 \\
\hline 5 & 30 & 8.4011 & 0.5024 & 16.7219 \\
\hline 6 & 35 & 10.6265 & 0.5024 & 21.1515 \\
\hline 7 & 40 & 10.7285 & 0.5024 & 21.3545 \\
\hline 8 & 45 & 12.9667 & 0.5024 & 25.8095 \\
\hline \multicolumn{5}{|c|}{ Tire inflation pressure $\mathbf{1 5 0} \mathbf{~ k P a}$} \\
\hline- & 0 & 5575 & 789 & 7.0660 \\
\hline 1 & 5 & 13.9823 & 0.5024 & 27.8310 \\
\hline 2 & 10 & 10.5462 & 0.5024 & 20.9916 \\
\hline 3 & 15 & 15.8095 & 0.5024 & 31.4680 \\
\hline 4 & 20 & 9.8039 & 0.5024 & 19.5141 \\
\hline 5 & 30 & 8.4034 & 0.5024 & 16.7265 \\
\hline 6 & 35 & 10.6256 & 0.5024 & 21.1497 \\
\hline 7 & 40 & 11.7927 & 0.5024 & 23.4727 \\
\hline 8 & 45 & 12.8618 & 0.5024 & 25.6007 \\
\hline
\end{tabular}


Table 2 (continued)

\begin{tabular}{|c|c|c|c|c|}
\hline $\begin{array}{c}\text { Sensor } \\
\text { No. }\end{array}$ & $\begin{array}{c}\text { Depth of } \\
\text { sensor, cm }\end{array}$ & $\begin{array}{c}\text { Compressing } \\
\text { force, } \mathbf{N}\end{array}$ & $\begin{array}{c}\text { Size of } \\
\text { contact area, } \\
\mathbf{c m}^{2}\end{array}$ & $\begin{array}{c}\text { Presssure } \\
\text { in the soil, } \\
\mathbf{N} \cdot \mathbf{c m}^{-2}\end{array}$ \\
\hline \multicolumn{5}{|c|}{ Tire inflation pressure 200 kPa } \\
\hline- & 0 & 5658 & 757 & 7.4742 \\
\hline 1 & 5 & 14.5518 & 0.5024 & 28.9646 \\
\hline 2 & 10 & 11.0551 & 0.5024 & 22.0046 \\
\hline 3 & 15 & 17.6685 & 0.5024 & 35.1682 \\
\hline 4 & 20 & 10.5789 & 0.5024 & 21.0567 \\
\hline 5 & 30 & 8.3707 & 0.5024 & 16.6614 \\
\hline 6 & 35 & 10.7516 & 0.5024 & 21.4005 \\
\hline 7 & 40 & 11.2418 & 0.5024 & 22.3762 \\
\hline 8 & 45 & 13.3754 & 0.5024 & 26.6230 \\
\hline
\end{tabular}

The variation of pressure with the soil depth under the front wheel of the $40 \mathrm{~kW}$ New Holland tractor is given in Figure 7. It can be seen that for the three tire inflation pressures, the variation curves follow a similar trend. The pressure exerted on the soil tends to decrease as the depth increases to 10 $\mathrm{cm}$, and then rises to a depth of $15 \mathrm{~cm}$, after which it follows a sharp downward curve to a depth of 30 $\mathrm{cm}$, and then there is a slight increase at the maximum tested depth of $45 \mathrm{~cm}$.

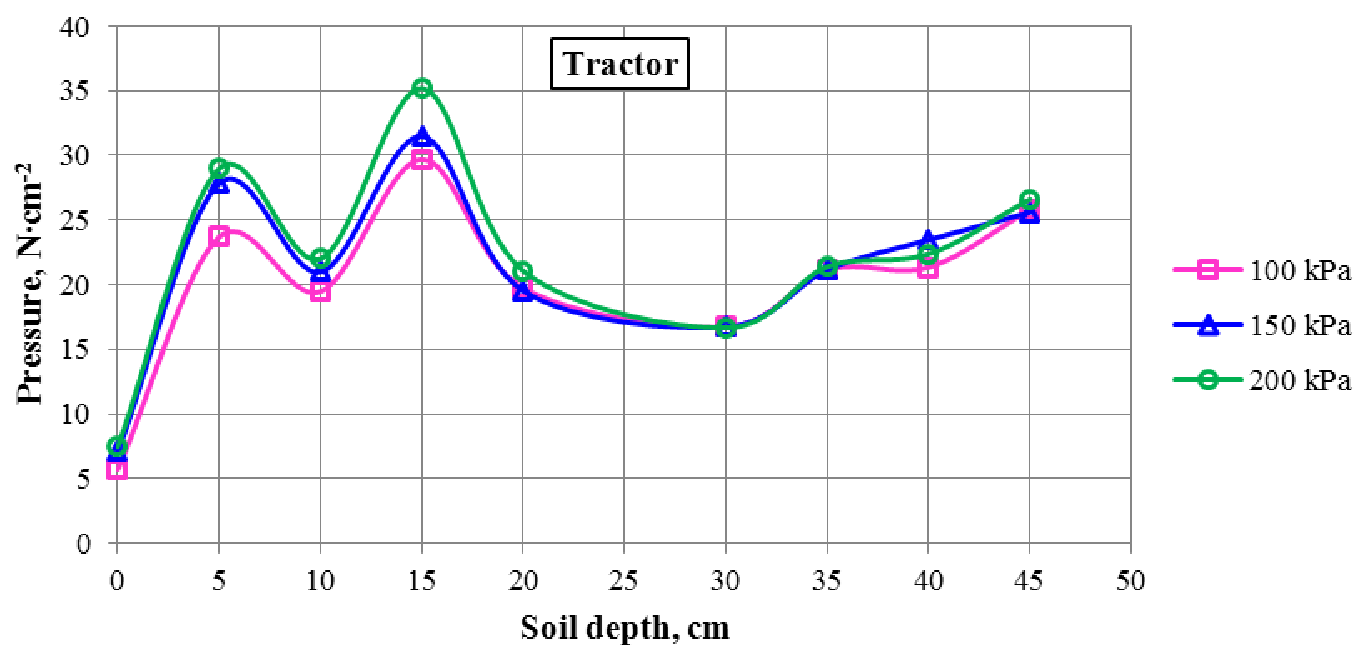

Fig. 7. Variation of pressure with soil depth, under front wheel of tractor

By comparing the results presented in Tables 1 and 2, regardless the tire inflation pressure, the highest value of pressure in the soil is recorded at $15 \mathrm{~cm}$ deep. We can assume that, while operating on an agricultural field under the tested conditions, both the maize harvester and the tractor would mostly compact the topsoil. Experimental results show a general trend of pressure decrease on the depth between $15-30 \mathrm{~cm}$. Higher pressures are then located at $30 \mathrm{~cm}$ deep, and then they tend to increase in the subsoil at depths between $35-45 \mathrm{~cm}$. This variation trends show that a layer of soil, similar to the hardpan in agricultural fields, is concentrated at a depth of $30 \mathrm{~cm}$ and its presence can be due to repeated loadings applied on the soil during the tests.

Similar trends of pressure distribution in the soil are presented in [12], where under the front wheel of the $\mathrm{C} 110 \mathrm{H}$ harvester for $10 \mathrm{kN}$ compressive force, it was found that the soil pressure at 0-35 cm has uneven variation, and then follows a descending curve with the increase of the depth to $75 \mathrm{~cm}$. Under the rear wheel of the tractor $\mathrm{U} 445$ at $4.82 \mathrm{kN}$, the pressure exerted on the soil had at first uneven distribution, with a decrease at $5 \mathrm{~cm}$, increased slightly at $15 \mathrm{~cm}$, decreased at $25 \mathrm{~cm}$, and then increased at $35 \mathrm{~cm}$, and then decreased between $55-75 \mathrm{~cm}$.

However, literature studies [13] show that topsoil compaction could have a significant effect on the crop yield and it could manifest for years, but its negative effects could be alleviated by tillage, drying-wetting and freeze-thaw cycles, and by the action of soil biota. According to [13] subsoil 
compaction (occurring below $30 \mathrm{~cm}$ depth) should particularly be avoided during agricultural works, because it is persistent and the compacted layer cannot be removed by conventional tillage. In the studies [13; 14] it was found that compaction was more obvious in the topsoil at a depth of about $100 \mathrm{~mm}$ and it was greatly influenced by the contact area and contact pressure.

\section{Conclusions}

1. In the operation of tires it is necessary to apply measures to reduce their pressure on the soil, knowing that this parameter depends on the wheel load, tire inflation pressure, tire size and tire stiffness, the duration of load and soil conditions.

2. Under the wheels of the tested agricultural machinery, the pressure has uneven distribution with the soil depth. Regardless the type of machinery, wheel load and tire inflation pressure, maximum pressure was recorded in the topsoil at $15 \mathrm{~cm}$ depth.

3. Then the pressure followed a downward curve up to $30 \mathrm{~cm}$ in case of the tractor and $35 \mathrm{~cm}$ under the wheel of the maize harvester, followed by a slight increase to a depth of $45 \mathrm{~cm}$.

4. While operating in the field with the tested machines and under the specified conditions, we can assume that the topsoil would be compacted to a depth of $15 \mathrm{~cm}$ and that after multiple passages (assimilated to multiple loadings in tests) of agricultural machinery on the same surface of soil, a dense layer of soil would occur at $30 \mathrm{~cm}$ deep.

\section{Acknowledgement}

This work has been funded by the University "Politehnica" of Bucharest, through the "Excellence Research Grants" Program, UPB-GEX2017, Ctr. No.61/25.09.2017, internal number IS 25.17.03/2017 (COMPSOL)".

\section{References}

[1] Lee C., Schaaf T. The future of drylands, International Scientific Conference on Desertification and Drylands Research Tunis, Tunisia, 2006. Springer.

[2] Pytka J., Szymaniak G. Investigations of stress state in soil under tractor tyres, pp. 14-18. [online] [9.03.2018]. Available at: http://www.pan-ol.lublin.pl/wydawnictwa/TMot4/Pytka.pdf.

[3] Soil compaction. JRC European Commission. Soil Atlas of Europe. [online] [9.03.2018]. Available at: http://eusoils.jrc.ec.europa.eu/projects/Soil_Atlas/Pages/115.html.

[4] Wulfsohn D. Soil-tire contact area. Advances in Soil Dynamics. ASABE. vol. 3, 2009, pp. 59-84.

[5] Ungureanu N. Contributions to the modeling of artificial compaction of agricultural soil. Doctoral Thesis, 2015, University Politehnica of Bucharest, Romania.

[6] Nankali N., Namjoo M., Maleki M. R. Stress analysis of tractor tire interacting with soil using 2D Finite Element Model. Int J Advanced Design and Manufacturing Technology, vol. 5, no. 3, 2012, pp. 107-111.

[7] Batey T. Soil compaction and soil management - a review. Soil Use and Management, vol. 25, 2009, pp. 335-345.

[8] Xia K. Finite element modeling of tire / terrain interaction: Application to predicting soil compaction and tire mobility. Journal of Terramechanics, vol. 48, 2011, pp. 113-123.

[9] Ungureanu N., Vlăduț V., Persu C., Cujbescu D., Oprescu M.R., Voicea I. Study on the compaction under front and rear wheel of a $40 \mathrm{~kW}$ tractor on plowed soil. Proceedings of the $46^{\text {th }}$ International Symposium „Actual Tasks on Agricultural Engineering”, 2018, pp. 189-199, Croaţia, Opatija.

[10] Nguyen Van N., Matsuo T., Koumoto T., Inaba S. Effects of tire inflation pressure on soil contact pressure and rolling resistance of farm tractors. Bull. Fac. Agr. No. 93, 2008, pp. 101-108. Saga Univ.

[11] Maheshwari D.K. Bacteria in agrobiology: stress management. Springer - Verlag Berlin Heidelberg, 2012.

[12] Ungureanu N., Croitoru Șt., Biriș S.Șt., Voicu Gh., Vlăduț V., Selvi K.C., Boruz S., Maican E., Matache M., Manea D., Constantin G.Al., Ionescu M. Agricultural soil compaction under the action of agricultural machinery. Proceedings of the $43^{\text {rd }}$ International Symposium „Actual Tasks on Agricultural Engineering", Croaţia, Opatija, 2015, pp. 31-42. 
[13] Schjønning P., van den Akker J.J.H., Keller T., Greve M.G., Lamandé M., Simojoki A., Stettler M., Arvidsson J., Breuning-Madsen H. Soil compaction. Ch 6. JCR Technical Reports - Soil threats in Europe. Status, methods, drivers and effects on ecosystem services. A review report, 2016. Deliverable 2.1 of the RECARE project.

[14]Ziyaee A., Roshani M.R. A survey study on soil compaction problems for new methods in agriculture. Intl. Res. J. Appl. Basic. Sci., vol. 3, no. 9, 2012, pp. 1787-1801. 